\title{
COMPLEX SENTENCES WITH COLLOQUIAL EXPRESSIVE ELEMENT AS A COMPONENT OF LANGUAGE EDUCATION
}

\author{
Galina L. Sokolova', Anna L. Kolyago ${ }^{2 \star}$ \\ 1Assos. Prof., Mari State University, Russia, askgalinasokol@mail.ru \\ ${ }^{2}$ Assos. Prof., Mari State University, Russia, kolyago@yandex.ru \\ ${ }^{*}$ Corresponding Author
}

\begin{abstract}
In the modern world, with its diversity of languages and nations, the development of a linguistic personality is one of the main factors of language education. A language personality should possess the language competence that presupposes the possession of the theoretical norms of the language and their further use in the practice of speech use. The language personality must possess the phonetic and lexical grammatical norms of the language. Syntax, which gives the language a communicative and functional significance, is the highest level of the language system. It is in the syntax that the national specificity of the language manifests itself. Possession of it indicates the formation of a language personality. Complex thoughts that reflect the intellectual level of the individual are formed in the form of complex sentences. The emotionality and expressiveness of complex sentences are created due to the way they are organized and the use of syntactic figures of speech. Conversational and expressive elements in the structure of a complex sentence, due to their unintentional and informal nature, create additional shades of imagery and expressiveness in book speech. In the Mari language, the following elements of colloquial speech are introduced in the language of fiction to give a complex sentence imagery and expressiveness: conjunctions, particles, postpositions, interjections, onomatopoeic words and various types of repetitions. Complex and compound sentences are characterized by the use of all these elements of colloquial speech. Conjunctionless complex sentences, based on their structure, use the speech elements of repetition as an expressive means.
\end{abstract}

Keywords: language and education; language competency; Mari language; syntax; stylistics; complex sentence; expressivity; colloquial expressive elements of speech.

\section{INTRODUCTION}

The Mari language belongs in the Uralic language group to its Finno-Ugric branch. Writing has appeared relatively recently, in the XVIII century. This fact makes it possible to attribute it to the young written languages. According to the researchers of the Mari language, the Finno-Ugric proto-language has not yet had complex sentences. A complex idea, according to I. S. Galkin and E. N. Mustaev, was expressed by simple sentences following one another (Galkin and Mustaev, 2005). This fact explains the predominant use of conjunctionless complex sentences in colloquial and book speech. Mustaev notes that "In the Mari language, complex sentences began to develop ... only with the beginning of the functioning of the literarywritten language" (Mustaev, 1995). The colloquial Mari language is not as rich in complex sentences as the literary norm of the language. Many Mari linguists agree that the development of complex sentences was influenced by the syntax of the Russian language. Complex sentences in Mari have a small number of their own subordinate conjunctions and use conjunctions borrowed from the Russian language and they are often calques from the Russian language.

The emotionality and expressiveness of complex sentences are created due to the way they are organized and the use of syntactic figures of speech. Conversational and expressive elements in the structure of a 
complex sentence, due to their unintentional and informal nature, create additional shades of imagery and expressiveness in a bookish way of speaking.

\section{MATERIALS AND METHODS}

The relevance of the study is due to the fact that a complex sentence in the Mari language has not yet been subjected to systematic research and study from the point of view of its stylistic capabilities. The expressive possibilities of the elements of colloquial speech that are part of the structure of a complex sentence are an effective means used in the language of fiction to give the narrative imagery and expressiveness. The purpose of the study is to identify and analyze the elements of colloquial speech in complex sentences in the Mari language. This goal is achieved by using the method of synchronous description and analysis of the collected material. The aim of the research is to consider the expressive possibilities of complex sentences with elements of oral speech in the works of Mari authors. The object of the research is the stylistic potential of complex sentences in the works of Mari fiction. The practical value and significance of the obtained results lies in the fact that, firstly, they can be used in teaching syntax and stylistics of the Mari language, in giving special courses on these sections of linguistics. Secondly, they will contribute to the development of the language personality and the formation of language competencies. It is the most important and significant from the point of view of language education.

Our study continues a series of articles on the problem of stylistic syntax of complex sentences in the Mari language ( Sokolova, Kolyago 2019 a; 2019 б; 2020 a, 2020 b, 2020 c).

\section{DISCUSSION}

Complex sentences in the Mari language, in contrast to simple ones, are able to express more complex and diverse semantic relations and connections. Such sentences are also characterized by special stylistic possibilities. One of the productive ways of imagery and expressiveness in a complex sentence in the language of fiction can be attributed to the inclusion of linguistic elements of colloquial speech in book speech. As N. I. Formanovskaya notes, "... in order to give speech the character of informality, ease, possible brevity, dynamism, or, on the contrary, elongation of the utterance in comparison with the neutral norm, enhanced intonation, as well as the possibility of additional meaning, one uses the elements of colloquial speech" (Formanovskaya, p.144). Colloquial speech, included in the composition of a complex sentence, gives it a stylistic expressive character. In fiction, colloquial speech is used both in the author's characterization of characters and in their direct speech. The deliberate use of elements with reduced expressive coloration in literary speech creates expressiveness and emotionality of the narrative.

Colloquial expressive elements of speech that are part of complex sentences and give them imagery and expressiveness:

1) Particles, conjunctions, postpositions and interjections have stylistic connotation of colloquialism. All these elements can be often part of one complex sentence, for example:

Мыйын поп пуымо лӱмемже Пӧтыр огыл да, Епсей да, времаже годым авай ужален моштен, Пӧтырым ыштен. 'The name that the priest gave me was not Petor, Evsey, my mother was able to correct everything, Sha gave me the name Petor' (Chavain, 1980).

Эх, ӱдырем, ачат салтаклан ок кае ыле гын, тый тыге от иле ыле, да ачатым шучко-влак салтакыш пуэн колтышт. 'Oh, my daughter, if your father had not gone to the soldiers, you would not have lived like this, but your father was given to the soldiers by evil people' (Chavain, 1981).

Шке эрыкыште лиям ыле гын, тыйымат, Эвика, утарем шонем ыле, да ынде уке. 'If I had been free myself, and you, Eivika, would have been liberated, I think, but it is not so now' (Chavain, 1981).

Акпатырым салтакыш кучен нангайышт, курымешлан шонго ачаж деч, йӧратыме ватыж деч, изи ӱдыржӧ деч ойырышт, Сибирь мландышке нангайышт... 'Akpatyr was caught and taken away as a soldier, for the rest of his life he was torn away from his old father, from his beloved wife, from his little daughter, and taken to Siberia ...' (Chavain, 1981).

Клавий, «мӱкш гае ен-влак деке каем», манат ыле, ынде шонымет шуо: мӱкш гае ен-влак тевыс улыт. 'Claviy, you said, "I will go to people who look like bees", now what you have planned has happened: people, here they are, people who look like bees' (Chavain, 1981).

Ончыкыжо илышем кеч-могае лиеш гынат, ончылнем кеч-могай корно почылтеш гынат, шенгек ом чакне: лӱдде, тоштын, ончыко каяш вием сита! 'In the future, no matter what my life is, no matter what road opens up before me, I will not back down: I have enough strength to go forward without fear!' (Chavain, 
1981).

Нунын ӱмырышт кӱчык: кече лекме деч кече шичмешке веле - айда кеч ик кечегут ош тӱняште куанен илат! 'Their life is short: only from sunrise to sunset-let them live at least one day!' (Chavain, 1980).

2) onomatopoetic words, for example:

Окавий ошемеш, чеверга, да ошем кая, шинчавӱдшат чыл-чыл-чыл коеш. 'Okaviy turns pale, blushes, turns pale again, tears welling up in her eyes ' (Chavain, 1980).

Ӱмбалне кӱдырчӧ дӱр-дӱр-дӱр кӱдырта, мланде дыр-дыр-дыр чытыралтеш, мардежшат пуалтеш... 'In the distance, thunder rumbles dur-dur-dur, the earth shakes dyr-dyr-dyr, and the wind blows ...' (Chavain, 1980).'

Волгенче йолт коеш, кӱдырчӧ шыр-гор, чылт-чорт-чорт-шорт шокта, вара дӱр- дӱр- дӱр-р мӱгыралт кая. 'Lightning flashes, thunder thunders, then sings dur-dur-dur-r' (Chavain, 1981).

3) phraseological unit, for example,:

Адак Шемеч куван ик титакше уло: йӱаш пеш йӧрата, аракалан вуйжым пуа, манаш лиеш. 'Grandma Shemech has one sin: she loves to drink, she will give her head for wine, one can say' (Chavain, 1980).

Тудо шонымыжо семын марий калыкым савыркален кертеш, а марий калык - мемнан пурла кидна. 'He can turn the Mari people at will, and the Mari people are our right hand' (Chavain, 1980).

4) different types of repetitions, for example:

Кӧ мыланна полшынеже, кӧ эрыкан лийже - мемнан кашакышке ушныжо! 'Who wants to help us, who wants to become free-join us !' (Chavain, 1981).

Тый теве «мемнан ялым овда карген» манат, а мый манам: Кыстынчим юмо карген... 'You say «оur village was cursed by a witch", and I say: God cursed Kystynchi (Kystynchi - man's name)...' (Chavain, 1981).

Пӱртӱсын сылнылыкше меманан шӱмышкӧ ласкалыкым пурта, пӱртӱсын сылнылыкше икте-весынам адак утларак йӧратыкта. 'The beauty of nature puts kindness in our souls, the beauty of nature makes us love each other more' (Chavain, 1981).

\section{CONCLUSION}

Syntax and its stylistic potential are important and significant elements of language education. Thanks to the syntax, which is the highest communicative level of the language, human speech is organized. Stylistic elements give the speech imagery and emotionality, create expression and expressiveness of the utterance. Knowledge of the theoretical foundations of syntax and stylistics indicates the formation of a language personality and its mastery of language competencies. Complex sentences belong to one of the higher levels of language education, as they provide an opportunity to express deeper thoughts and judgments, in contrast to simple sentences. Complex sentences, along with the ability to express different types of relationships, can also establish logical connections between parts of a complex sentence. The imagery and expressiveness of complex sentences give the way the sentence is organized. After analyzing the materials borrowed from the books of Mari writers, we came to the conclusion that the elements of colloquial speech are often introduced into complex sentences to create imagery and expressiveness in written speech.

In the Mari language, the following elements of colloquial speech are used in literary speech to give a complex sentence imagery and expressiveness: conjunctions, particles, postpositions, interjections, onomatopoeic words and various types of repetitions. Complex and compound sentences are characterized by the use of all these elements of colloquial speech. Conjunctionless complex sentences, based on the peculiarities of their structure, use the speech elements of repetition as an expressive means.

\section{ACKNOWLEDGEMENT}

This research was financially supported by RFBR and Government of the Mari El according to the research project No 19-412-120002 «Stylistic syntax of compound sentences in the Mari language» 


\section{REFERENCES LIST}

Galkin, I.S., Mustaev, E.N. (2005). Финно-угроведенийын негызше. Морфологий, Синтаксис, Лексике. (р. 96). Mari State University. Yoshkar-Ola.

Mustaev, E.N. (1995). Mari language. Stylistics. (168 p.). Yoshkar-Ola: Mari Book Publisher.

Sokolova, G.L., Kolyago, A.L. (2019 a). Complex Sentences in the Mari Language. Proceedings of ADVED 2019- 5th International Conference on Advances in Education and Social Sciences. (P. 291-294). Istanbul, Turkey. .

Sokolova, G.L., Kolyago, A.L. (2019 в). Stylistic Features of the Compound Sentence in the Mari Language. Proceedings of ADVED 2019- 5th International Conference on Advances in Education and Social Sciences. ( P. 295-298). Istanbul, Turkey.

Sokolova, G.L., Kolyago, A.L. (2020 a). Expressive ways of reporting other persons' spreech in the Mari language. (P. 51-54). Proceedings of INTCESS 2020- 7th International Conference on Education and Social Sciences. DUBAI (UAE).

Sokolova, G.L., Kolyago, A.L. (2020 b). Knowledle of stylistic and syntactic features of complex sentences in the Mari language as a component of lanquage education (the case of parallelism). (P. 368-342). Abstracts \& Proceedings of ADVED 2020- 6th International Conference on Advances in Education. Istanbul, Turkey.

Sokolova, G.L., Kolyago, A.L. (2020 c). Language education and the evaluating principle of the expressiveness of speech in complex sentence in the Mari language (the case of syntactic figere of the period). P. 373-377. Abstracts \& Proceedings of ADVED 2020-6th International Conference on Advances in Education. Istanbul, Turkey.

Chavain, S.G. (1980). Collected works in three books. 1. Poetry, prose. (318 p.). Yoshkar-Ola. Mari book publishing house.

Chavain, S.G. (1981). Collected works in three books. 1. Poetry, novel "Ilnet” (318 p.). Yoshkar-Ola. Mari book publishing house.

Formanovskaya, N.I. (2015). Complex sentence: Semantic and stylistic aspects, 3rd ed. (240 p.). Moscow. 